\title{
Ambivalence, Paradox and the Poison-Remedy of Brazilian Improvisation: A Conversation with José Miguel Wisnik
}

\author{
Micaela Kramer
}

Translated by Micaela Kramer

José Miguel Wisnik is a professor of literature at USP (The University of São Paulo), as well as a musicologist, composer, singer, songwriter, and virtuoso pianist. His work bridges erudite and popular culture and poses this capacity to combine forms and registers as a central facet of Brazilian artistic and cultural production. Wisnik's numerous essays and books on literature and music, among other subjects, demonstrate an explicit concern for the conditions and loci in which these artistic forms are produced and embedded. His latest book, on soccer, is titled Veneno Remédio: O Futebol e o Brasil (Companhia das Letras, 2008) [Poison-Remedy: Soccer and Brazil].

Wisnik's other books include O Coro dos Contrários: a Música em Torno da Semana de 22 [The Chorus of the Contraries: Music And the (Modern Art) Week of 1922], (1977); O Nacional e o Popular na Cultura Brasileira [The National and the Popular in Brazilian Culture] (1982); O Som e o Sentido [Sound and Sense] (1989); Sem Receitas: ensaios e Canções [Without Recipe or Prescription: Essays and Songs] (2004); and Machado Maxixe: o Caso Pestana [Machado Maxixe: The Pestana Case] (2008). Unfortunately, as of this writing, none of his books has been translated into English, even though his corpus occupies a major place in Brazil's intellectual history over the past 35 years.

Wisnik has three solo CDs to his credit: José Miguel Wisnik (1989), São Paulo Rio (2000), and Pérolas aos Poucos (2003); and he is currently recording Indivisível, a double CD that will be released later this year. He composes soundtracks for theater and film, including Foreign Land (1996), directed by Walter Salles and Daniela Thomas, and Janela da Alma (2001), directed by João Jardim and Walter Carvalho. Wisnik has also composed several scores for the internationally acclaimed dance company Grupo Corpo, including Nazareth (1993); Parabelo (1997), composed jointly with Tom Zé; and Onqotô (2005), composed in collaboration with Caetano Veloso.

Together with Arthur Nestrovski-member and artistic director of the Symphonic Orquestra of São Paulo-Wisnik has also inaugurated a new genre, which consists of a combination of lecture and live music, called "aula-show" [lectureperformance]. He also writes a weekly column for the Rio de Janeiro newspaper O Globo, one of Brazil's major daily publications.

The planning for this interview went through several stages. Initially, we had conceived of it as a short, improvised conversation conducted over Skype, partly to accommodate Wisnik's busy schedule and partly to keep to the spirit of a journal dedicated to improvisation; yet, throughout what turned into a much lengthier process than expected, the piece metamorphosed in an interesting and perhaps symptomatic way, reflecting Wisnik's way of working, as well as performing under this journal's improvisational motif.

The first stage of the interview process consisted in sending Wisnik a list of written questions in preparation for our Skype conversation. The questions I sent were dense and elaborate, with lengthy quotations from a number of texts by Wisnik; with them I tried to show his engagement with improvisation in its various guises in Brazilian life and cultural production. Wisnik replied that the only way he felt he could fully respond to the questions was in written form, for he wanted to make sure to provide sufficient contextualization and nuance. Once he'd sent me a set of written responses, we would convene over Skype to go over missing points, eventually complementing the written responses with material from our conversations.

However, following this exchange, Wisnik had a surge of activity: he needed to complete an article for $O$ Globo and to travel to Bahia, where he was working on a new score for the dance company Grupo Corpo. When he returned to São Paulo, we resumed our email correspondence and Wisnik began sending separate email replies to each of my questions. These emails were interspersed by short Skype conversations in which we discussed practical matters, including questions of translation. Then, during one of our Skype sessions when we were discussing words and phrases that I was having difficulty translating-slippery terms with a plurality of meanings whose ambiguity often had to be sacrificed when rendering them in English-Wisnik began speaking so eloquently, and at such length, that I began to record our conversation in an effort to retain all the information he was giving me. My thought was to place 
his explanations in footnotes to help explain why I decided to leave a certain term in the original Portuguese rather than translate it. However, after a particularly inspiring remark, I mentioned to Wisnik that I was recording what he was saying, and I told him l'd love to include these spontaneous, improvised segments in our interview. He agreed.

When I asked him what he thought about the fact that I had to practically trick him into giving an oral, improvised interview, he remarked:

I thought it was great to be tricked. I think it's better this way [. . .] because I too need to trick myself! I can only do something if I trick this extremely conscious and critical attitude that takes over when I write. I interject a subject who argues with me, who gives limits to my improvisational self, with whatever cost this might have. I can therefore only write at the cost of tricking myself, but this depends on a lot of work! And it's really very interesting that this interview has mimicked this dual approach: the improvised and the non-improvised mode, which are the written and the spoken forms.

What follows is the result of a dual approach that combines written questions and answers with transcriptions of improvised oral conversations. I have decided to include both forms in the interview, interspersing them without necessarily elucidating which is which, although at times it may become clear from the style or the content of the text. Such a mixed genre for an interview on improvisation seems particularly appropriate: its final, hybrid form was unplanned and can thus be seen as an example of a certain spontaneity-an acting in the moment-which provides us with unexpected and unforeseen results. In the interview, Wisnik refers to the act of bricolage as a supreme instance of Brazilian improvisation. I can't help but see the work of putting this interview into its current form as a certain act of bricolage, one that entails the compilation of the various sources and material before me, the written responses and oral segments I feel immensely fortunate to have recorded and documented.

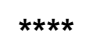

Micaela Kramer: Your work addresses literature, music, and soccer, and often touches on questions of race and mestiçagem $^{1}$ in Brazil, and also on certain Brazilian cultural and artistic tendencies and practices. This issue of the Critical Studies in Improvisation journal is dedicated to inquiring into whether there is something about Brazil, and Brazilians, that can be identified broadly in terms of improvisation, even if the word "improvisation" [improvisação] is replaced by other words or phrases that have improvisational valences. For example:

a) Do you think that the characteristic act of dribbling in Brazilian soccer, the "jogo de cintura" ${ }^{2}$ or the "jeitinho brasileiro",3 that one finds manifested in Brazilian music and culture, reveals something about a typical Brazilian attitude towards improvisation, and a certain ease in relation to circumventing rules?

b) Can we think of improvisation not only as an additional element in the Brazilian condition or way of life, but as an essential component of Brazilianness (if one can speak of such a thing)?

José Miguel Wisnik: I try to avoid the term brasilidade [Brazilianness] and its correlates, which might suggest the idea of a national essence. However, I do believe in the existence of contradictory lines of force that can be traced in multiple sites within cultural spheres and which allow for the identification of certain tendencies-even if these are complex ones. The composer Tom Jobim liked to say that "Brazil isn't for beginners." This sentence, uttered by one of our greatest artists of the twentieth century, conveys the idea that the possible inferiority complex derived from our "peripheral" condition is compensated by the fact that at least we don't fit easily into schematized or linear explanations. For a sociocultural formation that is both pro-slavery and of mixed race [mestiça], both baroque and syncretic; and where the boundaries between the sacred and the profane, the erudite and the popular, the public and private, are fluid, we oftentimes lean towards the modes of ambivalence and paradox. ${ }^{4}$

Taking soccer as a good reference, it is interesting to observe it as a sport where possession of the ball suffers from a high level of contingency (to use Hans Ulrich Gumbrecht's formulation). Because of this, it passes continually from one team to the other, and doesn't possess the characteristic appearance of the clear duel, divided between attacks and defenses, which is characteristic of volleyball, tennis, or baseball. The margin of indetermination, of imponderable variation, of chance and of interpretation, is much larger than in American football, where collective and previously rehearsed-if not ostensibly planned-moves form a structural part of the game. Soccer is a sport that both allows and asks for a much larger margin of improvisation on the part of its players. One might say that the Brazilian appropriation of the "Breton sport" reinforced this aspect, creating a famous style for what Pasolini defined as a more poetic than a prosaic discourse: the unexpected occupation of spaces, the emphasis on dribbling, on the jogo de cintura; as well as on physical readiness and on elliptical, curvilinear moves, rather than linear ones. When 
the famous player Zico became the coach for Japan's national soccer team, he was astonished to note that the Japanese players asked him to determine beforehand what they should do when they had the ball in the adversary team's penalty area and were in the position of scoring a goal. Such an expectation was symptomatic of a culture of obedience towards postulates of accumulated wisdom, which are formally passed on from master to disciple. This is in sharp contrast with the Brazilian manner of informal absorption of knowledge, usually determined in the act, and which depends on the momentary variables of the situation. This is the case, par excellence, of the attacking team's moves in the penalty area. In the Brazilian style, what counts is precisely improvisation.

In his classic text on Brazilian soccer, Negro, Macumba e Futebol, Anatol Rosenfeld writes that the descendants of slaves, who were abandoned to their fate without a national project after the abolition of slavery, found a form of work in the ball game that symbolically emancipated them from the atavism of slavery; however, "in a country that has never possessed the equilibrium of a puritanical work ethic," slave-work itself was oftentimes carried out as a game (85). This penetrating game of inversions between violence and festival, between the sphere of work and the sphere of play, between inadequately abolished slavery and the emancipation through play [pelo jogo], endow Brazilian soccer with the ambivalent and unresolved aspect of the pharmakon, of both the poison and the remedy, which is how I've titled my book, Veneno Remédio: o Futebol e o Brasil [Poison-Remedy: Soccer and Brazil].

MK: In your essay "Algumas questões de música e política no Brasil," ${ }^{5}$ you describe the origin of modern Brazilian music in Rio de Janeiro, and you write the following:

Popular music emerged for the market, transforming the binary European dances through African percussion [batucadas negras]. In other words, it emerged for the rising sound and radio industry, furnishing material for the urban carnival, wherein a kaleidoscope of social classes and races experienced its coming together in a country that had just recently left slavery behind, and had entered the 'mode of production of merchandise.' (204-205)

Do you think Brazilian music reflects a Brazilian spiritedness and wisdom, as well as an ability to transcend racial divisions and social hierarchies? How can we escape from possibly idealizing Brazil when we talk about this?

JMW: In order to escape the risk of idealizing Brazil and Brazilians, we need, from the very start, to refrain from postulating cultural superiorities, or even from positing an idea of "national character." Instead, as I've already mentioned, it's important to identify complex specificities. The powerful music of the Americas comes from the encounter between Europe and Africa in a new territory, and spreads from a few cities which constituted themselves as important pro-slavery centers: New Orleans, Havana, and Rio de Janeiro (along with the inestimable contribution of Salvador and Bahia). The Africanizing transformation and the hybridization took place in its own way in each of these sites. The European polka, which is the prototype of all popular, urban dance music, becomes ragtime in the United States, habanera in the Caribbean, and maxixe in Brazil. The rhythmics [rítmica] of these three genres from North, Central, and South America are equally contrametric [contramétrica]: that is, they base themselves on accentuations that fall outside of the tonic points [pontos tônicos] of the binary measure; they thereby create a texture of internal pulses, tending towards polyrhythm, which call for a swaying dance [dança gingada] full of swing. These rhythmics are different from the ones that predominate in Western Europe, which musicology identifies as cometric [cométrica]: that is, where the figures and rhythmic divisions double the tonic points of the measure.

MK: Could you say something about the terms cometric and contrametric that you've just used?

JMW: One used to speak in terms of syncopation [sincope], which is the more well known term, and which signifies the stressed rhythmic notes that fall outside of the fundamental accented beats of the measure. Tonic points are the following: if you have a binary measure, you have a beat that goes "one, two, one two, one two." The "tonic" points of the beat are precisely the place of the one and the two. If the emphasis falls outside of the tonic points of the "one, two" measure, we have what is traditionally called syncopation. To produce a more precise, musicological analysis, Carlos Sandroni, in his book titled Feitiço Decente, utilized a framework from African music analysis, adopting the terms cometricity and contrametricity. ${ }^{6}$ Cometricity is when the rhythmic figures repeat or "re-fold" [redobram] and confirm the tonic points of the measure. Practically all European music is this way (Mozart, for instance). Contrametricity is when you have figures that escape the "one, two" beat. These are the stresses that you find in African music, and that you also find in jazz, in Cuban music, and in Brazilian music. The terms cometric and contrametric aren't that common: they're kind of musicological neologisms. But cometric should be taken in the sense of something that accompanies the meter [métrica], and contrametric as something that goes against the meter and introduces elements that fall outside of the metric points [pontos métricos]. That's why the music has "swing" [fica swingada] and charm, because, as I've said, you have polyrhythmic pulses within the rhythm. 
MK: Can we think about the difference between European and Brazilian music as the expression of an ideological difference? One that is emblematic of a national character, linked to the capacity to improvise and to dribble certain rigidities, and which can result in important political consequences? Is it possible to generalize from music to politics, and to see the musical form as expressing a certain political attitude?

Moreover, do you see music as a privileged space that allows for an escape from rigid racial and class divisions? Or would music be a sphere that reflects a certain Brazilian ideology - a jeitinho brasileiro, even — that manages to free itself from an excluding European binarism, which, however, isn't circumscribed, or limited solely to the sphere of music, and which can also be found in literature, in the arts, and in other areas and discourses?

JMW: I find the study of the similarities and differences between what occurred in these three places [New Orleans, Havana, and Rio de Janeiro] and the analysis of the musical form and its sociocultural implications to be one of the most fascinating themes of comparative musicology. I raise the hypothesis that, in North American music, more specifically in ragtime, one finds the Africanizing syncopation combined with the protestant chorus and with martial music (of which the drums, as percussive instruments, are a synthesis). The ethos is, despite everything, more progressive and martial. In Brazil, with maxixe, one finds neither the protesting nor the martial trace: the music is more mercurial, circular, slippery, often turning on itself rather than "evolving." We tend to associate it with what the literary critic Antonio Candido has called "dialectics of roguery" [dialética da malandragem]: the mark of a sociability in which the boundaries between formality and informality (in family and close relationships, as well as in one's sex life, in work and leisure) are ambiguous and interpenetrable. The malandro [rogue], occupies an ambivalent place between order and disorder, between work and play [festa], legality and contravention, and is the subject, par excellence, of the carioca samba of the first decades of the twentieth century. ${ }^{7}$ Malandragem [roguery], can be originally related to a sector of free men in the slaveholding order who aren't slaves, yet who are dependant upon favors from proprietors, and who don't have a proper wage-paying job market in which to insert themselves, and who make a living from doing odd and sometimes illegal jobs [expedientes]. ${ }^{8}$ It is this ambivalent sector, in a slaveholding and mixed race society, which, for the most part, sets the tone to the imaginary for the modern Brazilian, of which carioca samba is one of the primary emblems. One of the characteristics of this imaginary is its refusal to fully introject a productive ethics, maintaining instead a labileness that dilutes obligations in play. Evidently, converse to the impositions of planning, such a mode of sociability circulates in an atmosphere of obligatory informality where the principle of improvisation rules as a mode of liberation against the hardships and the horrors of slave work. In this sense, samba was the people's response to a particular historical experience, and the primary matrix of a culture, which, from the twentieth to the twenty-first century, specialized in appearing to the world's eyes as the proprietor of a curious cutting-edge technology of leisure [tecnologia de ponta do ócio].

MK: I'm wondering how to translate your expression "tecnologia de ponta do ócio." The Michaelis dictionary translates "ócio" as "leisure," "inactivity," "laziness", "idleness", "indolence", or "sloth." Yet none of these seem to fully embody what is implied by the term "ócio" in Portuguese.

JMW: This makes me think of something John Gledson once said. Gledson is the translator of Machado de Assis into English, and he once told me about the difficulties he had translating certain terms which referred to work and leisure [ocupação e desocupação] in Machado de Assis. So I can only imagine the work you're going to have to translate words that pertain precisely to this sphere.

Ócio comes from the Latin word otium, and is the basis for the word negócio ["business"] —it is the nec-otium: the negation of otium. The Latin tradition and Latin cultures have thus preserved the idea that before business or work there was already pleasure, or leisure, or idleness [ócio]. While business doesn't correspond to this same matrix, and work seems to be the key word for the beginning of the world, ${ }^{9}$ the world surely began with God working! [Laughter] In Veneno Remédio, when I compare American football with soccer in the final part of the chapter "A Quadratura do Circo" ["The Quadrature of the Circus"], I cite an art critic who refers to the manner in which the United States assimilated French painting, and who says something interesting: Impressionism, with all its refinement, seemed flimsy to the Americans-a frivolousness without results. ${ }^{10}$ So the Americans adopted a form of painting where you in effect work the canvas: you throw it on the floor, you use it as an action-board the way the Abstract Expressionists did. And they transformed painting, displaying another conception of the canvas upon which one presents an action of work. In fact, Steinberg refers to the sense of the word "work" in the United States, and he mentions that in the military-in Vietnam, or in any other place-when soldiers returned from a battle or an incursion, one said: "the boys did good work." ${ }^{11}$ The idea is that actions are considered productive actions, which is why actions that aren't related to work or to production [ações ociosas] are difficult to name in English. 
MK: It's true. It's very interesting to consider the weight that the term "work" has in the U.S. We can also think of the expressions "a good job" or "a job well done" in English, which are used for a variety of occasions.

JMW: That's why when I composed the score Ônqotô for Grupo Corpo ${ }^{12}$ together with Caetano Veloso, [2005], we played with the expression Big Bang, which is precisely a kind of great, productive emanation at the beginning of everything. And we exchanged it for "fla-flu,"13 thus suggesting that the creative breath playfully uttered "fla-flu" as it created the universe.

MK: Your mention of your song "Big bang bang" makes me think of a question which l'd like to ask you regarding American and Brazilian music: Do you think we can draw a parallel between certain styles of Brazilian music and American jazz, such as the jazz that originates in New Orleans? Do we find the same freedom from binary structures in American jazz as we do in Brazilian music? And, if we don't find the same improvisation in Brazilian samba that is so characteristic of American jazz, can we look at the ginga ${ }^{14}$ or the roguery [malandragem] of samba as perhaps echoing the improvisational spirit we find in jazz?

JMW: Jazz gives a complex and refined form to improvisation, one that is codified in its harmonious and melodic syntax. The Brazilian improvisation we're talking about is essentially informal, and hasn't constituted itself as a genre. In an insightful essay, Lorenzo Mammi writes that the ideal model for American life is that of the professional displaying his distinctive competency. A birthday party imitates show business. In Brazil (Mammi refers primarily to the example of bossa nova), the model is that of the amateur-of the one who performs without any effort or work. A bossa nova concert (where Tom Jobim, João Gilberto, and Vinicius de Moraes would call each other by the nicknames Tomzinho, Joãozinho, and Poetinha [Little Poet], while playing in a rigorously professional way and performing at the highest level) imitates a family gathering or a get-together among friends. Jazz harmony is molarand is structured in blocks of chords [acordes] which are predisposed to melodic improvisation. The vocation here, including that of the voice, is instrumental. The scoring of the brass instruments is conspicuous and strong. Bossa nova's harmony is evasive and modulating [modulante], and it doesn't lend itself to the formalized turns of improvisation. Even the instrument's vocation is lyrical, vocal, and at the service of the words. The scoring for woodwinds and strings is fluid and airy. Jazz, Mammi concludes, is "the will to power"; bossa nova is "the promise of happiness."

MK: In your essay, “Algumas Questões de Música e Política no Brasil,” which I've already cited, you write:

In its beginnings in the 1920s and 30s, the ethos of samba is, in effect, an anti-ethos: together with roguery, it is a negation of a work ethic and of an exemplary conduct (achieved through a parodying farce in which one ironically simulates the possession of the appropriate conditions for the exercise of citizenship). In addition, this negative ethics is accompanied by a praise of orgy, by a giving in to the pleasure of dancing, sex, and drinking (all of which have been considered, since the Greeks, to belong to the order of pathos and not of ethos). Yet the "pride in being idle" [o orgulho em ser vadio] (Wilson Batista) also corresponds to a concealed ethics, given that, for the black man, the affirmation of idleness or leisure [ócio] is a victory over a minimal interval between slavery and the new and precarious condition of disqualified and fluctuating labor. Even though it may seem to be absent from popular music, the sphere of work projects itself within it "as a powerful inverted image." (205)

Is it possible to talk about an "ethics of roguery," which might be a way of dribbling and circumventing an exclusive and excluding system?

JMW: The ethos and pathos of malandragem certainly form an ambivalent mode of defense against the degrading exploitation of work. It is ambivalent because it isn't formulated as a direct protest or as an explicit refusal. Rather, it is achieved through ironic and self-ironic forms with which the derisive citizen [cidadão irrisório] creates a symbolically privileged status for himself, and which depends on his capacity to maneuver with words, with rhythm, with melodic inflections [entoação melódica], and with his body. Historically, we find its prototypical forms in the nineteenth-century novel, in particular in Manuel Antonio de Almeida's Memórias de um sargento de milícias [Memoirs of a Police Sargeant], analyzed by Antonio Candido in his essay "The Dialectics of Roguery," which I referred to before. Samba is what will give voice to the culture of roguery [cultura da malandragem] in the first decades of the twentieth century. One can say that composers who embody this lineage, such as Ismael Silva, Wilson Batista, and Geraldo Pereira, and whose field of action encompassed the neighborhood of Lapa in Rio de Janeiro, prevail until the 1950s.

Following this, Chico Buarque sang about the extinction of this emblematic figure in his memorable sambas and in his Ópera do malandro [Rogue Opera], about a figure who loses his maneuvering space and whose alternatives are either to insert himself in the labor market or to fall straight into roguery. On the other hand, the counterpoint to the 
rogue, and the reverse of this same coin, is the samba composer of melancholia, like the extraordinary Cartola and Nelson Cavaquinho. All of this is the aesthetic balance of a people's poetics that has shaped both the Brazilian imagination and a true Brazilian sentimental education. As we've seen, it has its specific, literal and dated manifestations, and at the same time, it leaves deep traces which can be found on several levels of the country's life. Its simultaneously positive and negative aspects—taken to the extremes of parody and tragedy-can be found in Mário de Andrade's 1928 rhapsody-novel Macunaíma-O herói sem nenhum caráter [Macunaíma-The Hero Without Any Character]. In it, the positive qualities of "our people's hero" (his versatility, cunning, enchanting seductiveness, and his capacity for improvisation) struggle without resolution with his negative qualities (his incongruence, his inability to sustain projects and to introject limits).

MK: Could you say something more about the "cidadão irrisório" that you refer to? Is this a citation, or is it your own expression?

JMW: The expression "derisive citizen" [cidadão irrisório] doesn't come from my reading of any other text. I myself began to use it a while ago, and, when I refer to the malandro, and to the malandro in samba, I use the figure of the "derisive citizen." What I mean by it is the following: In Noel Rosa's song, ${ }^{15}$ for instance [Wisnik sings]:

\begin{tabular}{|l|l|}
\hline O orvalho vem caindo & The dew keeps falling \\
\hline Vem molhar o meu chapéu & Come wet my hat \\
\hline E também vão sumindo & And [they] also start to disappear \\
\hline As estrelas lá no céu & The stars up in the sky \\
\hline Tenho passado tão mal & I've been hit pretty bad \\
\hline A minha cama é uma folha de jornal & My bed is a sheet of newspaper \\
\hline & \\
\hline Meu cortinado é um vasto céu de anil & My curtains are a vast, indigo sky \\
\hline o meu despertador é um guarda civil & My alarm clock is a civil policeman \\
\hline (Que o salário já não viu!) & (Who hasn't yet seen his salary!) \\
\hline & \\
\hline O orvalho vem caindo... & The dew keeps falling... \\
\hline
\end{tabular}

In other words, we have the idea of the individual who lives in the street, yet [Rosa] presents all of this as if this man had a house: he has a bed, he has curtains, he has an alarm. . . and he has a salary. However, the bed is a sheet of newspaper, the curtains are the open sky, the alarm is the policeman's whistle, and the policeman hasn't received his salary, much less has the protagonist received his! [Laughter] This is therefore an ironic and self-ironic construction of a dispossessed figure who doesn't have the signs of citizenship or of social inclusion, but who nevertheless works with this lack of signs, composing an ironic portrait in which he would have these things. His identity is [thus] composed through bricolage. That is, it's a kind of imitation, or the mimicry of an identity and of an image of himself, which is composed entirely from scraps. There's a samba by João da Baiana called "Cabide de molambo" ["The Rag Hanger"] which is always the example I give for this-the man who walks around showing off with things; he dresses himself, he has a jacket, a tie, he has a bed, a table, he eats-yet everything is made out of scraps. That's what a rag hanger is-he is the rag hanger. And, in a certain way, he constructs his precarious citizenship. It's a precarious condition because the individual makes do with odd (if not illegal) jobs. ${ }^{16}$ He isn't literally or completely expelled from social life, but he has to constitute his identity with whatever he finds. I would say that this is the essence of improvisation. It is the matrix, in the sense of a base of reference, for a culture of improvisation: the bricolage with which you constitute an identity in a precarious condition. And this, in turn, becomes the matrix for a culture, wherebeyond this social condition, which is that of these individuals who live in such a precarious condition-the very capacity to get by even in adverse conditions becomes a reference and an affirmation of life.

MK: All this is implied by the expression "derisive citizen"?

JMW: Yes. [Laughter] The precariousness in which he lives, and the way he bypasses this precariousness, through improvised gestures and loopholes [expedientes de improvisação] with which he builds or cobbles an identity for himself. There is a kind of ironic self-consciousness that this is a game, yet that one must therefore build one's identity as a game.

Moreover, I believe that all of this implies a culture that doesn't give much credence to the idea that the signified is attached to the signifier; because there is always a zone of ambivalence in which the signifier slides; it oscillates. In order to construct an identity that has a component of play [componente de jogo], one assumes that language also plays, that it too is a game [um jogo]. And being a game, the signifier doesn't only transmit the signified that one's 
consciousness projects upon the sign; rather, one realizes that things speak, and they do so in a fugitive and oscillating way.

MK: And do you think this particular kind of relation with language is rendered explicit in Brazilian culture and in its music?

JMW: I do. I think that cultures in which one supposes that the signifier and the signified are soldered together, and that words march in corporate lines-where you accept that the signifier is glued to the signified, and that the signs are glued to things-you don't have this maneuvering space where language isn't so closed off to the meanings of words. One thus accepts that a word can say something and its opposite at the same time. A word might oscillate, and it might point towards a nucleus of indetermination which you accept as being part of the play of language. Thus in Noel Rosa, one finds "O Samba, a prontidão e outras bossas, são nossas coisas, são coisas nossas" [Samba, promptness/pennilessness and other bossas are things that belong to us, are our things]. I discuss the word "prontidão" in Veneno Remédio, for it is the ability to reply immediately to things, but it is also to be penniless! This word is thus simultaneously an aptitude and a deficiency, a lack. The word "bossa" is also replete with indetermination. It's what gave us the expression "bossa nova." But bossa is a physiological term and refers to the bossa craniana [cranial bulge], which I also write about in Veneno Remédio. "Bossa" is also "an aptness for," "an ability," "an aptitude," that can't be translated by the word "skill," which is the ability to exercise a specific action. ${ }^{17}$ Bossa is the ability to exercise or do things that aren't well determined in advance, because it will depend upon a margin of improvisation.

MK: Can we see "bossa" in relation to ginga?

JMW: Yes, we certainly can. Ginga is also a bodily disposition that is more or less adaptable [maleável], a bodily dynamic that signals one's ability to respond to situations with solutions that one comes up with in the moment.

MK: So, like bossa, it's more of an attitude or a disposition than a specific knack or skill.

JMW: Precisely. It's not a talent, nor is it a specifically trained skill. In other words, there is no formal training for it. It's a kind of accumulation of experience with a basis on intuition, and it remains in a fluid zone of informalization [não formalização], which nevertheless recognizes itself as an ability to act and to respond to given situations.

MK: In your essay "O famigerado"18 on Guimarães Rosa, you make a contrast between the sertão-the backlands of the Northeastern interior-and the roguish Rio de Janeiro, "where the law isn't configured, but continually slips into its inversion" (143). Could you say something about the importance of location and the role that is played by different Brazilian cities? Are roguery and a certain improvisational spirit related to location? In other words, are there Brazilian cities that are more auspicious to this improvisational spirit, and which are therefore, in a way, more "Brazilian" (if "Brazilianness" can even be defined or regarded as a spirit of roguery and the possibility of "ginga")? Could you also say a bit more about what makes Rio into a place of roguery? Why is Rio the city of the malandro, and not, for instance, São Paulo?

JMW: Salvador is the center, both economically (sugar cane) and culturally (the great prose writer Antonio Vieira and the great poet Gregório de Matos) of the Brazilian seventeenth century. Minas Gerais is the economic and cultural center of the eighteenth century (the gold cycle, Aleijadinho's oeuvre, ${ }^{19}$ the Arcadian poets, ${ }^{20}$ sacred music). Rio de Janeiro is the political and cultural center of the nineteenth century (the Empire, ${ }^{21}$ its literary, musical, and artistic culture, linked to the coffee economy in the Paraíba Valley). São Paulo is the twentieth-century "capital," growing, in just a few decades, at an overwhelming rate to the rhythm of industrialization, and leading the modernist movement in the arts. I regard Bahia and Minas as having their roots deeply plunged in the Brazilian colonial unconscious, bathed in the culture of the Afro-Brazilian festivities, syncretically sacred and profane. Rio engenders the first forms of a modern urban culture, including music that is initially commercialized through the circulation and sale of musical scores, and, later, through the gramophone and radio, giving voice to the black and mulatto populations. During a large part of the twentieth century, it is a partly Portuguese, partly African city-a center of the Empire's power, aristocracy, and bureaucracy, at the same time that it is an ebullient ground of festive popular culture. Like the very functioning of institutions, the sociability of the middle layers of the "free men in a slaveholding order" often oscillates between formality and informality, order and disorder, the cabedal and carnival. ${ }^{22}$ Salvador, the cities of Minas Gerais and Rio de Janeiro, are thus anchored in cultural processes that allude to the country's pre-modern foundation. São Paulo belongs to another time. 
MK: Shifting gears a bit, l'd like to turn to your latest book, Veneno Remédio, and to the thoughts on improvisation that you develop in relation to soccer. You write,

Even though it follows the same ludic principle-the dispute for the ball commanded by one's feet in an uneven, risk-laden field-the pelada ${ }^{23}$ obeys neither the scheme nor the finalism of soccer. [. . .] Its horizon isn't delimited by the rigid quadrature of sportive conduct, nor by the implacable circle of life and death, but rather, by the imaginary and fluctuating lines that allow for a certain tangential exit. The matrix of Brazilian soccer as formulated by Chico Buarque's parodic myth is a sort of magnification of the principle of the erotic continuity of soccer. (220)

Do you think we can see the pelada - this space of the ludic, as you put it-as not being circumscribed by meaning or by sense-making? And if so, can we see this as a reflection of a typically Brazilian ability to not circumscribe everything to the need to signify?

JMW: We can say that the "pelada" is a ludic space that is concerned neither with accountability, planning, nor results. The flow of the ball and of the players' moves is more important than the pacing of the score [andamento do placar]. The pelada was certainly an important factor in the development of the more playful and inventive substrate of Brazilian soccer, which was evidently adapted to and coupled with the need for organization, dispute, competition, and results--once there was an investment in the competitive and official dimensions of the game. But it is certainly a symptomatic indicator of a culture that isn't committed to productive accumulation.

Concerning the disposition to not "signify," I would say that perhaps a recognizable trait in several Brazilian cultural manifestations is less the absence of meaning or of signification than an intrinsically baroque ease to let the signifier slide. The pun, the sliding of meanings, the parodying swerve, indicate that signified and signifier aren't necessarily glued to each other, as if welded. Rather, by allowing one to catch a glimpse of its provisional and conventional nature-which can become the object of a witty game [jogo chistoso]—repressed contents can rise to the surface. I'm going to risk a comparative example. In the United States, as far as I know, because of its unusual and foreign aspect, the name Barack Hussein Obama can be stigmatized by voices from the right as a foreign body that should be extirpated from the American organism. But this gives no credit or pays no attention to the play of signifiers. In a culture with a baroque sensibility, like the Brazilian one, it would be irresistible-in parodic and in anarchic free spirit-to see the name as possessing the cipher to Bush's two sworn enemies: Saddam Hussein and Osama Bin Laden, names that resonate homophonically and paronomastically with a sort of return of the repressed. Meaning what? Meaning that opposites dance an unpredictable dance, and that they appear where one least expects them to.

To add to this, of course there is an awareness in the U.S.A. that the name has a strangeness to it, has double meanings, etc; that the great enemies of the U.S.A., of Bush, are ciphered in Obama's name, and that they return through the signifier in the form of the elected president. The question is, what does one do with this? I'd say that in a culture where the signifier and the signified are glued together, one remains in a state of surprise: "how could he have won [the election]?" Or "what does this mean?" My hypothesis is that here in Brazil, in a culture where the signifier and the signified are not glued together, this means that life is a game, that opposites play, and that the signifiers carnivalize ready and given images. This is therefore part of a larger game than consciousness or of the intention of [any] agents. It means, in a certain way, that one pleasurably accepts carnival [aceita gozosamente o carnaval].

MK: Do you think that one finds a more explicit discourse about such questions in Brazil?

JMW: Yes, I think so. I say this always in that vein --not Brazil as a whole, but, rather, that one can find tendencies or lines of force in Brazilian culture that somehow carnivalize this and extract from it a parodic balance; not the stigma given by the rightwing about Obama for having a strange name. I'm referring to the thought about wit, and I'm citing Freud. What l'm saying is that the signifier speaks through the unconscious, and that besides being black, the winner of the presidential elections who succeeded Bush is "Brazilian" in quotation marks-he's ambivalent. He brings the effect of displacement in his name, and he brings to the name of the president of the United States the names of the supreme enemies of the American nation. If you were to take this seriously, you'd say "he's the devil, he's Satan." However, you can also say that language plays, signifiers slide, opposites return when one least expects it.

MK: In the section of Veneno Remédio I referred to earlier, you also mention that the one who gave a "definitive poetic and parodic formulation to the mythic narrative of soccer was [the musician and composer] Chico Buarque" (217). Do you see a strong connection between Brazilian music and soccer? What causes a great Brazilian composer to be inspired and moved by the aesthetics of soccer? Does this have something to do with a certain exemplary Brazilian sensibility? 
JMW: It is, in fact, noteworthy that the popular musicians [artistas da música popular] in Brazil oftentimes exhibit the wish to be soccer players, while soccer players express the wish to be musicians. It's certainly possible to see a contrametricity [contrametricidade] of samba as analogous to the comings and goings of the dribble.

MK: In Veneno Remédio you write about the reign or the legacy of the malandro turning into a reign of marginality, and you formulate it as a transition from the "dialectics of roguery" to the "hard dialectics of marginality" in a country ravaged by the harsh and explicit violence of organized crime.

We've been talking about an improvisational spirit or legacy in Brazil connected to the tradition of the malandro and his role in samba. Would you like to say something about present-day tendencies and the role of improvisation in contemporary Brazil? Can we see the ambivalent relation to the law and to juridical and political authority in terms of a national improvisational character? For instance, in a tendency to dribble or to circumvent authority? Is it possible to trace a genealogy of Brazilian outlaw violence (so much in vogue today in the media and in cultural production) starting from a tradition of ambiguous relations to the Law and to the State? And can we therefore frame the problem of violence in large Brazilian cities as a result of the legacy of roguery that we've been tracking?

Finally, do you think there's still room for the ginga of the malandro and for a fluid and improvisational spirit, or do you think we're leaving it irrevocably behind and entering something more rigid, with less fluidity between spheres and registers?

JMW: I think it's important to say that the socio-cultural substratum of roguery is very strongly related to informality, to prontidão (which, again, means both "promptness," and "pennilessness"), and therefore to the attitudes of nonplanning of an improvisational culture. I think that, in a certain sense, these elements form a part of a pre-modern Brazilian history and are a strong substratum that marks Brazilian life. Yet, in a way, they correspond to a cycle-in which such forms of sociability were at their height—with conditions that have changed quite drastically, beginning after the fifties, with the deactivation of the field where the malandro reigned. I'm referring to the literal malandro, that malandro that you already detect in Memórias de um Sargento de Milicias, and who can therefore administer a space between formality and informality, between the so-called order and disorder. As Chico Buarque's song notes, this is no longer possible: the workers have been expelled to the suburbs, to the factories, or have been confined to the slums, and can no longer exercise this oscillation between formality and informality, between order and disorder, through music. On the other hand, we can find roguery in the pure sense of making use, or of taking advantage [aproveitamento], which is a trait that we need to consider at all times.

Everything that we've been talking about-that is, this Brazilian ambivalence-is intelligible only when it is seen through the lens of the idea of the "cordial man" [homem cordial], as formulated by Sérgio Buarque de Holanda, who belongs to a society that has very tenuously marked frontiers between public and the private spheres, and where you can't clearly demarcate the distance between the public and the private. This ranges from questions of personal interactions, such as the one bossa nova musicians display in public performances, which was the example I gave previously. It is distinguished from the jazz show, where the public performance imitates and stylizes the meeting among friends. This is an aesthetic stylization, of an extremely high order, of just such a transition between the public and private sphere. Another example would be the mode of interaction that consists of calling someone immediately by você [the informal "you"], or of calling people by nicknames. On Brazilian soccer teams-this is starting to change, in a way-players have always been called by nicknames, which was the joke [brincadeira] I was also making with your name. I was playing with this tendency, with what we call hypocoristic, which is the nickname that infantilizes the adult.

In Brazil, we tend to call our public heroes by names that connote familiarity, as if they were children in our homesfrom Pelé to Lula. And, as far as I can tell, we don't find anything like this anywhere else in the world. These are certainly symptoms of everything we've been talking about, and they indicate a porosity between the public and the private. This also leads to festivity, because the porosity between public and private is what fosters the carnival tradition, (as Roberto DaMatta analyzes it), which arises from the permeability between the spaces of the street and the home. Now, this also means that the State is treated as something private, and that personal and private interests prevail over the law. For good or for bad, the jeitinho, adaptability and the like, are forms through which personal relations_-and therefore personal interests_-prevail, or have very often prevailed, over public interests. This is all deeply ambivalent, and therefore both positive and negative. I therefore think that forms of impunity, corruption, parapolice violence, affirmations of privilege, and, in a last analysis, extremely inadequate distribution of income, are also connected to this. Thus, at the same time that this ambivalent nucleus produces the highest cultural productions, it also produces the most terrible distortions of collective life. This is why I don't have a purely positive vision of the 
Brazil that I'm describing. And this is precisely why my book is called Veneno Remédio [Poison-Remedy]: I reflect on the pharmakon.

Brazil is a drug, with all the ambivalence that the word contains; and, historically of course, modernization, industrialization, and a series of factors have modified these relations, which is why we can't describe Brazil as a mere continuation of a culture, or of the sociability of pure improvisation that we've been talking about. It's clear that forms linked to planning, and an entire entrepreneurial culture-inspired by North America-have an extremely strong influence in contemporary Brazil, and enter into a dialogue, or a counterpoint, with the tradition that is more inclined towards informality, to a lack of planning, to unproductiveness, and in truth, to creativity and to the value of spontaneous creativity. I think it's a real question: what will the transformation of this country be like?

MK: To go back to what you were saying about planning: at the same time, when we refer to planning, we can't not think about Brasília, don't you think? After all, Brasília is the example, par excellence, of planning-of the planned city.

JMW: Exactly. The planned city and an important affirmation of the possibility of planning —that is, of a Brazil with no street corners and no informal bars [botecos]! And whose streets aren't the "old, straight and crooked street" ["rua antiga, estreita e torta" $]^{24}$ of Portuguese colonization, which Sérgio Buarque de Hollanda refers to when he writes that the Portuguese sowed cities [semeavam cidades] while the Spaniards paved or tiled cities [ladrilhavam cidades]. So [Brasília] is at the same time something profoundly Brazilian, and it is precisely planned! This is a fascinating theme: the Brazilian nature of Brasília affirming itself as a sort of zero mark of what opposes itself to the Portuguese colonial foundation. Now, right after Brasilia [was built], Clarice Lispector writes a wonderful piece about Brasília, Caetano Veloso composes the song "Tropicalia"; and I think that, in a way, both are responses that express the extent to which Brasília is somehow foreign to Brazil, and Brazil is foreign to Brasília; and yet we have this enigma that Brasília is Brazil, even though Brazil is so fundamentally different from Brasília.

MK: Another paradox to add to the paradoxes which you mention.

JMW: Precisely. It's a new paradox that modernism introduces. In a certain way, Sérgio Buarque de Hollanda said that if Brazil were to modernize itself, it would cease to be Brazil, and if Brazil remained Brazil, it wouldn't modernize itself. This was the dilemma. And I think that the dilemma of Macunaíma is the same dilemma we find in Sérgio Buarque de Hollanda's Raízes do Brasil. Nevertheless, I believe that, for better or for worse, Brazil has modernized itself and continues to be Brazil, and it continues to be Brazil without fully modernizing itself. And here you have paradoxes that l've formulated fully in the last chapter of my book Veneno Remédio. We also certainly need to look at Rio de Janeiro, which is the niche par excellence of the culture of roguery since the nineteenth century, including samba and everything else. And, at the same time that the favela becomes the locus of marginality, of drug trafficking, and of organized crime-which utterly modifies the image of the Brazilian morro ${ }^{25}$-you nevertheless still find a certain porosity between the state and crime, between authority and the bandit, in an infinite range of mediations that will give rise to the norm for criminality. It's difficult to trace the boundary and to establish the division, and in this sense this is the "dialectics of roguery," just as you find it in Antonio Candido.

All this is an interrogation into contemporary Brazil, and I think it adds to what we've already said, so that it doesn't seem as if we're simply praising the roguish Brazil [o Brasil malandro]. Now I affirm the way I end Veneno Remédioso perhaps you could cite it. In the end, if we were to connect positive aspects—which I am still convinced ofconcerning the Brazilian capacity for improvisation, l'd say that "one of the most original propositions to come out of our sketch of civilization [is] the breath that escapes the productivism without respite, the capacity for communication between multiple logics, and a profound lightness" (430).

Because I believe the combinations among multiple logics is an important aspect of all this. If you have an Aristotelian logic, which is a logic that opposes itself to paradox (if you have something that is different from another, if $A$ is different from B, then A can't be equal to B), you have the logic of the excluded third, or the excluded middle. In the end, this is the basis of logic or of scientific rationality. At the same time, however, one finds a different logic in Brazil: $A$ is different from $B$, and $A$ is at the same time equal to $B$. In short, we find that opposing and excluding things can, at the same time, come together. I think this is an ability to combine logics; it certainly isn't an incapacity to be efficient! I think Brazil has shown the ability to be efficient and is doing so without foregoing its improvisational versatility. Take soccer, for instance: if it were pure art, pure entertainment, pure play, it wouldn't win any championships. And yet our soccer has won five world championships. Tom Jobim composed a kind of fugitive, modulating, harmonically refined music with no commercial appeal, and yet it's one of the most performed in the world-at a certain moment only the Beatles were played more than Tom Jobim. Thus. what we have, in given moments, is a combination of efficiency and playfulness. 
MK: Before we end, l'd like to ask you about the improvisation in your own work. In an interview with Arthur Nestrovski, ${ }^{26}$ you describe your creative process in improvisational terms, and you remark that you feel more at ease talking about a subject than you do when you write about it. You also mention that speaking in public has an inevitable component of improvisation that you can't do without.

Do you see the element of improvisation in your way of working as an intrinsically Brazilian attitude or phenomenon, or, perhaps, as a Brazilian "symptom" in your education and in your relation to your work?

JMW: On this subject, I'll limit myself to citing the poet, philosopher, and songwriter, Antonio Cicero, who says that in the North American university culture, greater value is given to the paper, ${ }^{27}$ while the improvised speech runs the risk of sounding irresponsible and academically inconsequential. In Brazil, one tends to consider the paper boring, while the improvised speech and pronunciations in real time arouse admiration.

MK: However, in this interview you seemed to shy away from the improvisational, spoken mode --for instance, by asking to reply to my questions in written form.

JMW: I use improvisation when I speak. When I write, I suffer enormously writing every word, because I need to give shape to the improvisation that in speech occurs spontaneously and fluently. In speech it's fluent. And I improvise in the sense that I have a script, I have certain things that I've prepared, but I don't have a completed text at the moment when I speak in public. So I go and say things that I've already formulated; I speak as if it were the first time, and differently each time, because the paper isn't ready. I think it's an attitude that is linked to the value given to improvisation, and which prevails, diffusely, in Brazil. When I nevertheless have to write, when I need to give shape to this-I don't go about writing fluently, like one who improvises. In my writing, I need to simulate the fluency that occurs when I speak.

MK: Yet I can't help but find it interesting and rather curious that the improvised interview had to happen as if by chance, don't you think?

JMW: Absolutely. And then you pressed "record"!

MK: In medias res. . .

JMW: Yes: without my being aware, in medias res, . . . and, in fact, that's when we said things that we hadn't touched upon, and which weren't in the written text. I think you can incorporate all this.

MK: What do you think about the fact that I practically had to trick you?

JMW: I thought it was great to be tricked. I think it's better this way. . . because I too need to trick myself! I can only do something if I trick this extremely conscious and critical attitude that takes over when I write. I introject a subject who argues with me, who gives limits to my improvisational self, with whatever cost this might have. I can therefore only write at the cost of tricking myself, but this depends on a lot of work! And it's really very interesting that this interview has mimicked this dual approach: the improvised and the non-improvised mode, which are the written and the spoken forms.

\section{Notes}

1 "Mesticagem refers to the mixing of races. It carries a political and cultural valence, as well as a biological one, and it played a prominent role in Latin American state ideology. For "mesticagem" ideology in a Brazilian context, see the writings of Gilberto Freyre. [All notes are the translator's unless otherwise indicated.]

${ }^{2}$ Jogo de Cintura, an expression used to characterize a certain attitude or ability, which literally means "waist game," refers to the flexibility and ease someone displays in adapting to situations.

${ }^{3}$ This expression literally means "Brazilian way" and refers to a manner of circumventing norms or rules, of achieving something through personal charm or other informal means. 
${ }^{4}$ Here, as in subsequent uses of the term "popular," which translates the word popular in Portuguese, the term is being used to refer to production by poor people who don't belong to the upper, literate, or cultivated classes. In other words, to those who don't belong to the letrado class of intellectuals.

${ }^{5}$ This essay, whose title can be translated as "Some Questions on Music and Politics in Brazil," was originally published in the book Cultura Brasileira-Temas e Situações, edited by Alfredo Bosi (São Paulo: Ática, 1987). It has been subsequently published in Sem Receita: Ensaios e Canções, edited by Arthur Nestrovski (São Paulo: Publifolha, 2004).

${ }^{6}$ Editors' Note: Sandroni's use of the terms "cometricity" [cometricidade] and "contrametricity" [contrametricidade] derives from the pioneering work of ethnomusicologist Mieczyslaw Kolinski and also from ethnomusicologist Simha Arom's subsequent use of Kolinski's framework.

${ }^{7}$ Carioca is someone, or something, originating from Rio de Janeiro.

${ }^{8}$ The term employed by Wisnik is expedientes, which, as Wisnik noted in conversation, is symptomatic of an ambiguous and ambivalent culture. What is difficult to convey in translation is precisely the ambiguous status of the term in relation to legality and illegality: "expediente" can refer both to odd jobs and to illegal work.

${ }^{9}$ Both "business" and "work" are in English in the original.

${ }^{10}$ Wisnik is referring to Leo Steinberg and his book Other Criteria: Confrontations with Twentieth Century Art. See Veneno Remédio, 146-147.

${ }^{11}$ As Leo Steinberg writes in Other Criteria, "But to be workmanlike is an absolute good. Efficiency is self-justifying; it exonerates any activity whatsoever. It is the active man's formalism-a value independent of content. As the marine captain said after a battle near Conthien in South Vietnam-'It was definitely a good night's work'" (60).

${ }^{12}$ Grupo Corpo is a Brazilian dance company created in Belo Horizonte in 1975.

${ }^{13}$ The expression fla-flu refers to the famous and popular Rio de Janeiro soccer teams Flamengo and Fluminense. The expression refers more specifically to a match between the two rival teams. The expression was first used by the journalist Mário Filho in 1969, and has since become emblematic for the rivalry between soccer teams in general. The CD cover for the recording of Onqotô has an epigraph by the Brazilian writer Nelson Rodrigues: "o fla-flu começou quarenta minutos antes do nada" ("fla-flu began forty minutes before nothingness"), a phrase that is cited by Caetano Veloso and José Miguel Wisnik in their song "Big bang bang."

14 The term "ginga," will be discussed and defined by Wisnik later in the interview. The Brazilian Michaelis dictionary defines the verb "gingar" as "to incline from one side to the other when walking." What interests us here, however, is the figurative use of the term.

${ }^{15}$ Noel de Medeiros Rosa (Dec. 11, 1910-May 4, 1937) was a carioca samba composer, singer, bandolim and guitar player. Noel Rosa's music entered the public domain in 2008.

${ }^{16}$ Again, the term Wisnik uses here is expedientes, which refers to the ambiguous zone between legality and illegality.

${ }^{17}$ The word "skill" is employed in English in the original.

${ }^{18}$ This essay is published in Sem Receita: Ensaios e Canções (São Paulo: Publifolha, 2004).

${ }^{19}$ The artist known as Aleijadinho [Little Cripple] (1730-1814), whose name was Antônio Franciso Lisboa, was an influential sculptor and architect. Due to a degenerative disease that caused a progressive loss of movement in his hands and feet, he worked with the help of instruments that his slaves would attach to his limbs. 
${ }^{20}$ The Arcadian poets belong to the eighteenth-century Brazilian literary movement known as Arcadismo, which was inspired by the European literary movement of the same name. The designation "Arcadianism" is a reference to Arcadia, a region of the Peloponnese in Ancient Greece, considered an ideal of poetic inspiration. The literary movement took hold mainly in the state of Minas Gerais. It was also known as Neoclassicism, since most poets sought to follow the European neoclassicist conventions. Arcadismo ended in Brazil in 1836, giving way to Brazilian Romanticism.

${ }^{21}$ Brazil became the seat of the Portuguese colonial Empire in 1808, when the Portuguese regent, later King João VI, relocated the government to Rio de Janeiro, fleeing Portugal during Napolean's invasion. On September 7, 1822, King João VI's son, Pedro, declared Brazil's independence from Portugal and was acclaimed as Pedro I, first Emperor of Brazil. Pedro I was succeeded by his son, Pedro II. The Empire lasted until November 15, 1889, when a coup d'état inaugurated a military dictatorship.

${ }^{22}$ The way Wisnik is employing the term cabedal presents a significant difficulty for translation. At first, I considered translating it with the term "capital," which would convey one of the meanings of "cabedal," and is an acknowledged translation in the Michaelis dictionary. "Capital" would also preserve the alliteration and the play on words present in the phrase "cabedal e carnaval". However, upon discussing the translation with Wisnik, it became clear that "capital" was an inappropriate choice. Wisnik's explanation and his definition of cabedal were so compelling that I decided to include them here rather than to attempt an approximate translation and to lose the complexities of the term, which are linked to a very specific historical situation.

Here we're back to the John Gledson dilemma: [the translation of] words becomes difficult due to the fact that they are bound to another culture. I believe the word Cabedal shares the same root with capital. However, it was Antonio Candido whom I heard employ this expression to denote the universe of possessions in a poorly capitalized world. In other words: to refer to a world that isn't very financial. We are therefore dealing precisely with a world of owners and proprietors who possess land, slaves, and such, but who don't necessarily have money, much less applied money. The word capital is thus treacherous in this sense.

${ }^{23}$ Pelada is a soccer game played only for fun.

${ }^{24}$ This is a citation from Caetano Veloso's song "Tropicalia" (1967).

25 "Morro" means hill, but is used to refer to the raised ground in urban areas which have been settled upon illegally, giving rise to slum settlements-the famous favelas.

${ }^{26}$ This interview, which also includes the participation of Luiz Tatit and João Camillo Penna, is published in Wisnik's Sem Receita: Ensaios e Canções. The passage I'm referring to is the following:

I experience an ease in talking about the themes I work on, in the moment-as long as they've had the possibility of maturing a bit-in the pressure of the moment. [. . . That is, it's a narrowing down, at the moment of speaking, towards something that gains an oral form then and there, with an indispensable component of improvisation, without which it wouldn't seem to have any allure. Once this happens, one would think that I could easily write about it. But that's not the case. This is something that remains an obscure subject for me. Because writing confronts me with other demands, as if they were other nooks or corners [desvão] pertaining to the theme, which I need to resolve [dar conta] in the moment of writing. (46061)

${ }^{27}$ In English in the original. 


\section{Works Cited}

Bolle, Willi, et al. "Estética do futebol: Brasil vs. Alemanha." Pandemonium Germanicum 2 (1998): 67-104.

Buarque de Hollanda, Sérgio. Raízes do Brasil. 1936. São Paulo, Companhia das Letras, 2006.

Candido, Antonio. "Dialética da Malandragem: Caracterização das Memórias de um Sargento de Milícias." Revista do Instituto de estudos brasileiros 8 (1970): 67-89.

DaMatta, Roberto. Carnavais, Malandros e Heróis: Para uma Sociologia do Dilema Brasileiro. Rio de Janeiro: Rocco, 1997.

De Almeida, Manoel Antonio. Memórias de um Sargento de Milícias. 1854. São Paulo: Ateliê Editorial, 2000.

De Andrade, Mário. Macunaíma; O Herói Sem Nenhum Caráter. 1928. Rio de Janeiro: Agir, 2008.

Mammi, Lorenzo. “João Gilberto e o projeto utópico da bossa nova.” Novos Estudos Cebrap 34 (Nov. 1992$)$ : $63-70$.

Rosenfeld, Anatol. Negro, Macumba e Futebol. São Paulo: Perspectiva, 2007.

Sandroni, Carlo., Feitiço Decente. Rio de Janeiro: Jorge Zahar, 2001.

Steinberg, Leo. Other Criteria: Confrontations with Twentieth-Century Art. New York: Oxford UP, 1975.

Wisnik, José Miguel. O Coro dos Contrários: a Música em Torno da Semana de 22. São Paulo: Duas Cidades, 1977. . Nacional e o Popular na Cultura Brasileira. São Paulo: Brasiliense, 1982.

. O Som e o Sentido. São Paulo: Companhia das Letras, 1989.

. Sem Receita: Ensaios e Canções. Ed. Arthur Nestrovski. São Paulo: Publifolha, 2004.

. Machado Maxixe: o Caso Pestana. São Paulo: Publifolha, 2008.

Veneno Remédio: O Futebol e o Brasil. São Paulo: Companhia das Letras, 2008. 